\title{
Eugene Garfield-60 Years of Invention and Innovation
}

\author{
Alexander M. Grimwade* \\ Retired, Bala-Cynwyd, PA, United States
}

Keywords: Eugene Garfield, entrepreneur, innovator, information science, science communication

\section{INTRODUCTION}

Gene Garfield was a serial entrepreneur of the best kind-full of ideas, constantly inventive, never satisfied, pushing himself and his staff, always on the edge of bankruptcy as his ideas and ambitions got ahead of his cash flow. Gene was an unusual mixture of academic researcher and businessman, though his academic curiosity sometimes conflicted with commercial reality.

The range, variety, and sheer number of innovative publications and information services that Gene was involved in developing are quite astounding. Many are now merged into the Web of Science, some are published by other companies, some no longer exist, some continue in other forms. I am steering clear of discussing citation indexing, which is Gene's greatest claim to fame among information scientists. Instead, I discuss some of his other publications and products, particularly those I was personally involved with.

Gene was a man driven by a thirst and a passion to make all knowledge accessible in as many forms as possible and as fast as possible. In his late twenties and early thirties (1950-1955), he envisioned many of the services and publications that he spent his life bringing to reality. He was frustrated by the slow pace and conservatism of traditional abstracting and indexing that he saw in government and non-profit scientific societies. He invested time and energy in trying to get his ideas adopted and financed by the government and those societies. He wanted the huge sums of money and effort being poured into innovative scientific research by governments and industry in the 1950s and 1960s to be reflected in new methods for fast and easy communication of scientific results among scientists, taking advantage of the machines that were becoming available for data storage and management.

Although starting a for-profit corporation was for him the less preferred path, out of impatience and frustration and despite financial risk, Gene began to develop and publish information services for scientists. He thought of himself as a sort of academic and he called himself an "information scientist." Originally he called himself an "information engineer," but he was informed that only qualified and chartered engineers could use that title. He called his company the "Institute for Scientific Information." The name itself suggests an academic rather than a commercial organization. He managed ISI in a collegial, unconventional, and somewhat chaotic manner, because corporate management was for him only a means to the end of producing the best and most useful information systems for scientists. He emphasized product innovation over corporate cash flow, which inevitably led to a series of financial and organizational crises. He often stuck with products that were slow to be accepted or even unlikely to come to fruition. Finally, he was quick to see the possibilities of new technologies in helping ISI to reach its goals. Mainframe computing machines, first with punch cards and later tape drives and disk drives, personal computers, CD-ROMs, online data services, the web, computer graphics-Gene and his colleagues at ISI grabbed them all and were in a hurry to make practical use of them.

Here, I discuss four very different projects Gene developed over the course of 60 years-three of which I worked on with him and one which made him famous in the community of research scientists.

Most of the historical details in this article come from personal recollections, Garfield's own writings (Garfield, 1973-1993) and a biographical interview on the Web of Stories (Garfield, 2009). 


\section{CURRENT CONTENTS (CC)}

Gene's original claim to fame and the achievement for which he was best known in the scientific community for many years was $C C$.

For me, as a young bench biochemist in the late 1960s, CC was essential weekly reading. It was a ridiculously simple idea, namely the photographic reproduction of the contents pages of key research journals, often before they were even available in the library. CC, printed on thin airmail paper to keep postage costs down, was a handy pocket-sized booklet. It became an incredible time-saver for scientists who were quickly becoming overwhelmed by the flood of new journals from mostly European commercial publishers-Elsevier, Pergamon, North Holland, Springer, etc., and the rapid expansion of existing journals.

Before ISI, Gene had created a couple of current awareness publications. While working at the Welch Medical Library at Johns Hopkins University in the early 1950s, he developed a small publication called Contents in Advance which covered journals in documentation and library science. Subsequently, in 1956, Gene started his own company-Eugene Garfield Associates, which produced Current Contents in Management. However, it failed to find a receptive audience and closed down after a few years.

Gene was aware that several pharmaceutical companies were providing their own research scientists with in-house contents page services. He agreed in 1957 to start such a service for pharmaceutical company use-with a minimum subscription of 25 copies per corporate customer. Soon individual scientists were asking for personal subscriptions and CC was born in 1958. It was a bare bones publication covering about 150 journals primarily in the Life Sciences. Like any good startup, Gene did not work out of an office, but, as he liked to say, out of a "chicken coop" in the backyard of his home in Thorofare, New Jersey (Garfield, 2009).

Gene was never satisfied with keeping things simple. Every activity he was involved with grew larger and more complex as new features were added and more subject areas were covered. $C C$ grew at a rate of about 10 journals covered per month. This was also a time when science research was booming and the more established journals were exploding in size. The CC formula was soon duplicated in other fields, with a Physical Sciences edition added in 1960 and a Chemical Sciences edition in 1967. In 1969, three new editions arrived-Education, Behavior/Social/Management Sciences, and Agriculture/Food/ Veterinary Sciences.

The CC collection of publications was constantly being pushed to expand by publishers who were keen to have their new journals covered by $C C$, by the relentless increase in size of established journals, and by Gene's personal mission to cover everything important in every subject.

By the late 1970s, there were seven editions of CC covering over 4,500 journals (Garfield, 1973-1993) (Figure 1).

But this expansion is only a small part of the CC story. At the same time as $C C$ was expanding in journal coverage and number of editions, it was evolving into something more than just a collection of reproduced contents pages. The issues became more and more of a weekly magazine, eagerly anticipated by scientists to keep them not only informed, but also entertained.

To make CC more useful, a keyword index was added in the late 1950s. This included single words from every title listed in the journal contents pages. This allowed readers to skip the arduous

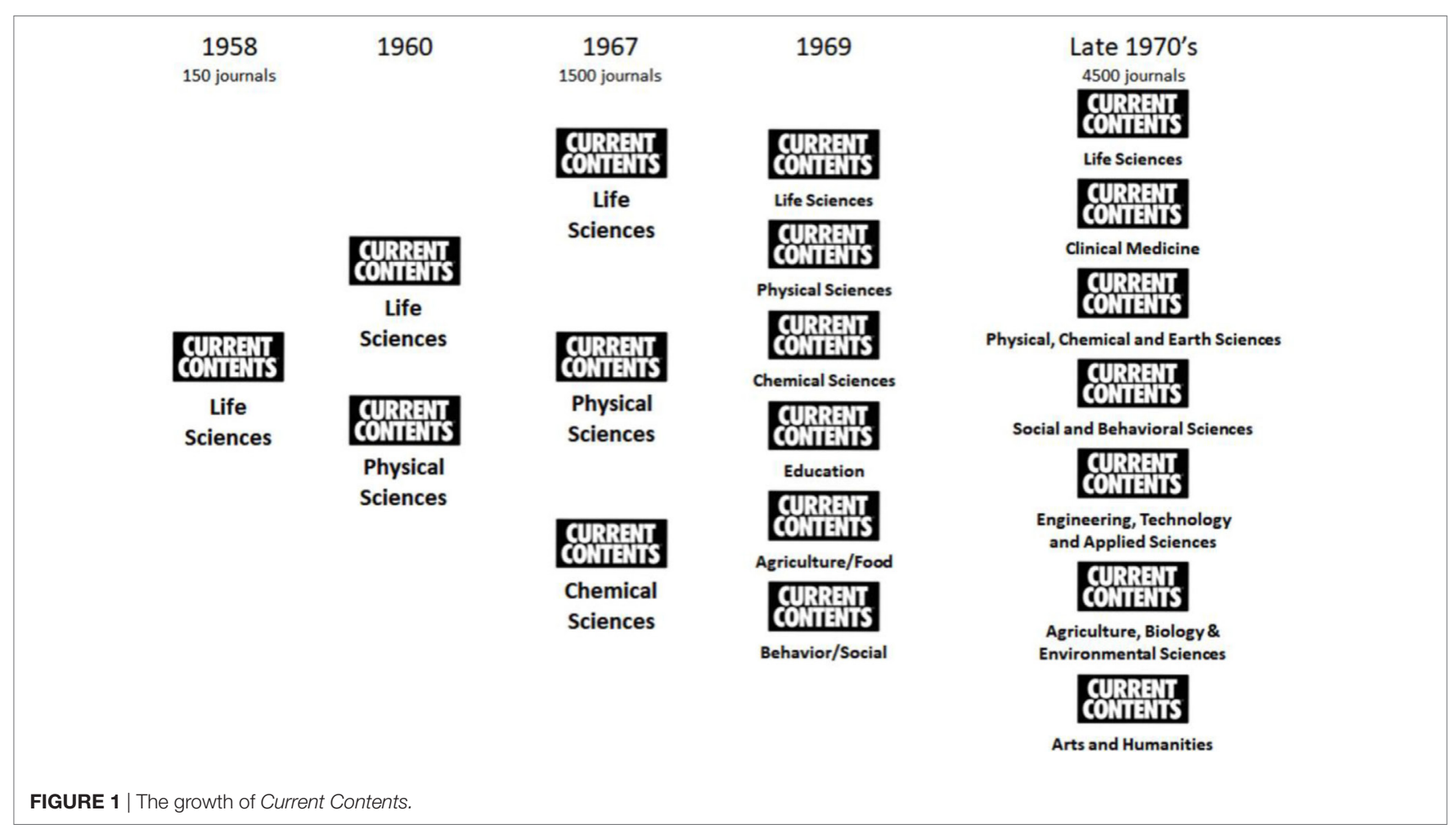


task of scanning hundreds of article titles and to pinpoint individual articles of interest. Later, ISI developed a separate service called Automatic Subject Citation Alert (ASCA) which allowed subscribers to create an alert profile of keywords, author names, journals, and cited papers. This came in the mail weekly in the form of a printout of article titles and publication information, author names, and addresses.

In 1960, an author address index was added to CC. This was created to allow readers to send reprint requests to the authors of papers they were interested in. The idea of reprint requests and personal libraries of reprints seems quaint in the world of electronic journals and instant access, but reprints were a vital part of keeping up with research in your field. No library, and certainly no individual, could afford to subscribe to every journal that might contain a paper of interest, so reprints were a vital part of scientific communication. The number of reprint requests a scientist received was also taken as an indication of the importance or interest in a particular piece of research-this was before "impact factor" became a concept that every scientist knew and obsessed over. I remember visiting one biochemistry department in a midwestern US university in the early 1970s where the faculty's research papers were pinned on a notice board and a piece of string from each paper led to a pile of reprint request cards - the height of the pile was taken as an indication of the value or importance of the work described.

In conjunction with $C C$, ISI also developed a service called Original Article Tearsheet Service (OATS), later renamed "The Genuine Article." ISI had a huge library of research journals provided by publishers whose journals were listed in CC. These back issues were cannibalized or photocopied to provide reprints quickly and on demand. Although it was traditional practice for authors to send reprints to practically anyone who requested them, the OATS service was more effective and efficient.

ISI also developed cleverly designed "Request-A-Print" cards for scientists which included a peel-off address label for the reprint provider to attach to the reprint envelope.

Not to leave any stone unturned, ISI combined the ASCA alert service with the tear sheet service to create "personalized journals" - a collection of reprints from any journal that published articles that fit the user's interest profile.

The author address directory soon led to the publication of a directory of publishing scientists, which cumulated all the authors and their addresses from every issue of CC into a single volume. In 1969, it contained names and addresses of over 150,000 active scientists.

Other services and indexes printed in CC included a publishers' address directory, to allow readers to contact the publishers of journals either for subscription inquiries or to submit papers for publication and a regular cumulative journal index, which allowed readers to trace the contents pages of their favorite journals.

We can see from this brief overview how every product and service that ISI produced gave rise to another potentially helpful aid to scientists and made access to the research literature they needed easier, more convenient and-most importantly-faster.

Before Gene's activities in the 1950s, current awareness services were non-existent, and abstracting and indexing services were manual and extremely slow, run by non-profit or governmental organizations. Chemical Abstracts, for instance, was three years behind in publishing its abstracts in the late 1950s. Gene might have wanted to be an academic information scientist, but the tools and data he needed to fulfill his mission were not available, and it was not possible to build them in an academic or non-profit environment. He needed speed-a rapid development cycle, immediate results, and short publication delays.

In 1962, Gene started to write occasional short articles for CC under the heading "The Informatorium." He soon changed this to "The Information Scientist" and subsequently to "Current Comments." At first, these articles were short and infrequent, but they gradually grew longer and more substantive. The topics were initially confined to descriptions of new ISI products and services but ranged wider and further as the years went by. By 1972, there was an essay in every issue of CC, many on topics directly relating to ISI products, but also discussing publication practices, citation analysis, copyright law, author ethics, and Nobel prizewinners.

Soon, in addition to topics more-or-less related to ISI businesses and to the use of citation indexes, Gene was covering topics of more peripheral interest such as electronic translation, the postal service, dyslexia, jet lag, the saxophone, twins, hypnosis, wine-making, and cockroaches. Altogether, during the 30-plus years from 1962 to 1993, Gene published over 1,000 essays, which were eventually collected into 15 volumes and published as Essays of an Information Scientist (Garfield, 1973-1993). Of course, Gene could not write all these essays without help and there was a significant editorial staff employed to research, write drafts, and edit the essays.

Current Contents eventually included other editorial features as well. Best known of these is "Citation Classics" where the authors of highly cited papers were commissioned to write a brief commentary on why their paper had made an impact (Garfield, 1977). These commentaries were also collected and republished in book form.

A "Current Book Contents" section and a "Calling Attention To" section listing recent books were added. This of course, led to a book ordering service. ISI took orders from $C C$ readers and acted as sales agent for the book publishers.

Also included were regular cartoons from Sidney Harris, and a Press Digest, where notable articles in newspapers and magazines were briefly summarized.

As a young PhD student I spent too much time in the library and not enough time at the bench, according to my $\mathrm{PhD}$ supervisor. For me, $C C$ was the best form of therapy. With its mixture of essential information, useful indexes and access tools, and pure entertainment it was as important and interesting as the latest issue of Nature or Science.

Like many other scientists, I got to know Gene Garfield from his thoughtful and sometimes revealing essays. But then I met Gene in person.

\section{THE ISI ATLAS OF SCIENCE}

In 1973 and 1974, Henry Small, who joined ISI in 1972, developed techniques for mapping the structure of science based on 
cocitation clustering of Science Citation Index data. In the early 1980s, ISI published two hefty volumes of maps of science under the title Atlas of Science (Garfield, 1981, 1984). Although Gene was sure that scientists and librarians would be fascinated by the maps and the brief essays describing them, the volumes were not a commercial success, so he decided he needed a more active editorial hand to make the cluster analysis come alive.

I was working in Cambridge (England) at the time as publisher of the Trends review journals for Elsevier. I met Gene in London in 1984. I recognized him immediately from his photo in CC, but was surprised by his orange socks, his unruly hair, and his multicolored tam-o'shanter-style cap. After lunch, where Gene talked about pretty much everything except the reason for our meeting, he invited me to his hotel room, where he produced a huge bag crammed with printouts of cocitation cluster maps. The bed became "Physics," the coffee table was "Social Science" and the floor "Biomedical Science." Because the floor was the area I was most interested in, we were soon crawling around the floor laying out the maps according to their relationships. It was certainly the most unusual and the most interesting interview I have ever had. By January, Gene had offered me a job in Philadelphia and by the summer of 1985, my family and I had moved from Cambridge to Philadelphia. Such was the power of Gene's infectious enthusiasm and creativity.

At ISI, I was generously supported and the Atlas of Science project developed into a series of quarterly journals in biomedicine with reviews written by eminent research scientists. The topics reviewed were in emerging fields of science identified by citation cluster analysis. The first issues appeared in 1987 and were well received (Garfield, 1987) (Figure 2).

In the mid 1980s ISI was involved with several other expensive innovations These included the launch of The Scientist, Gene's long-envisaged newspaper for scientists, development of a CD-ROM based version of the Science Citation Index, the development of SciMate software for management of bibliographic information, and several others. All these put a strain on ISI's unconventional management structure and an even greater strain on ISI's cash flow. A partial sale of the company in 1988 led to the closing of several of ISI's new and unprofitable product lines including the Atlas of Science, and I was out of a job.

At this time, Gene personally took over the publication of The Scientist, which was also faced with closure, and he personally ran it outside ISI for many years. A few years later, Gene was completely bought out of ISI and the company was taken over by the Thomson Corporation (which in 2008 became Thomson Reuters). Gene no longer had a formal role in the running of the company he had founded and became primarily a respected spokesman and figurehead, with time to devote to research, writing, publishing The Scientist, and being involved in many other ventures and personal quests.

\section{THE SCIENTIST}

Like many of his ideas, the concept of The Scientist was one that Gene worked on for many years before it materialized. It was another element in his quest to provide scientists with all the information he thought they needed to develop their careers and to stay informed. He first thought of it as a daily newspaper that would track emerging scientists and research fronts, in the same way as the Wall Street Journal tracks stocks. It would be a development of $C C$, with all the editorial elements that $C C$ readers loved, including of course, editorials written by Gene. The launch of The Scientist in 1986 was chaotic-a potential partnership with The Economist in London collapsed, ISI was stretched beyond
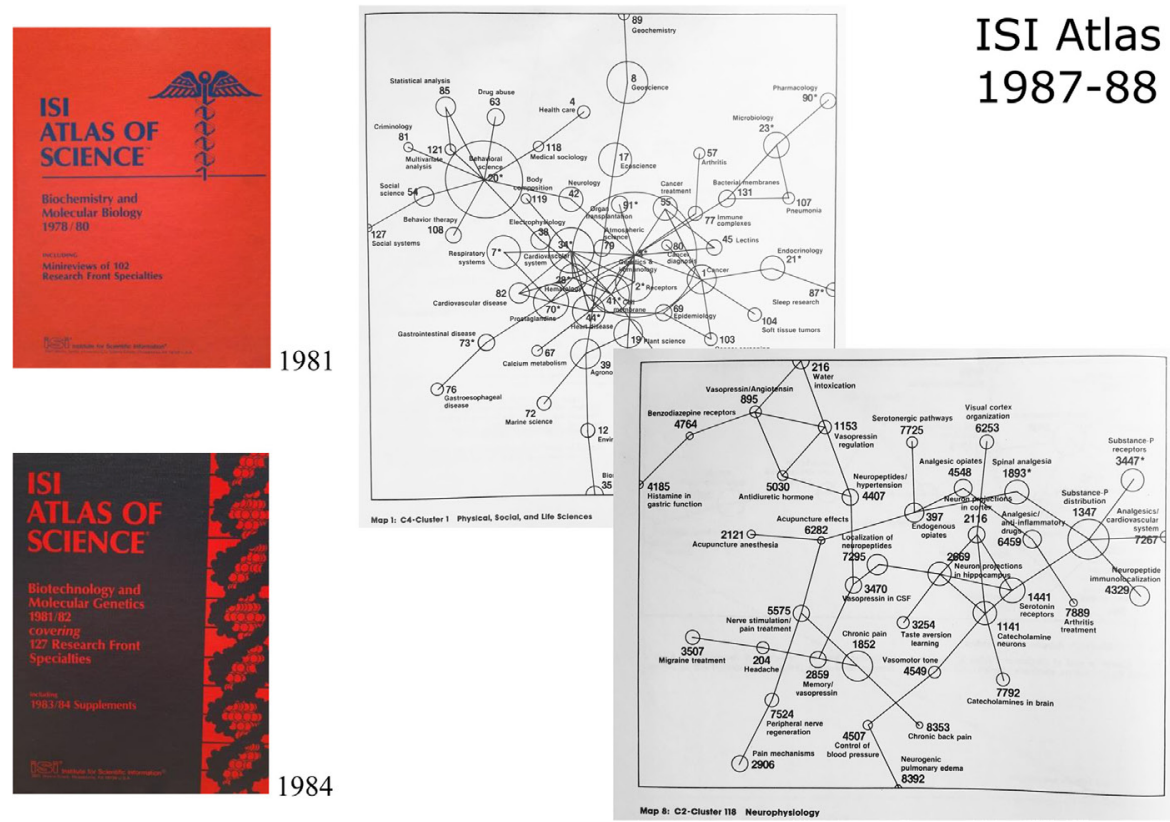

ISI Atlas of Science 1987-88

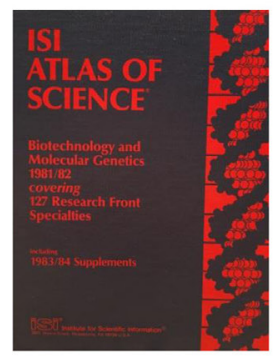

1984

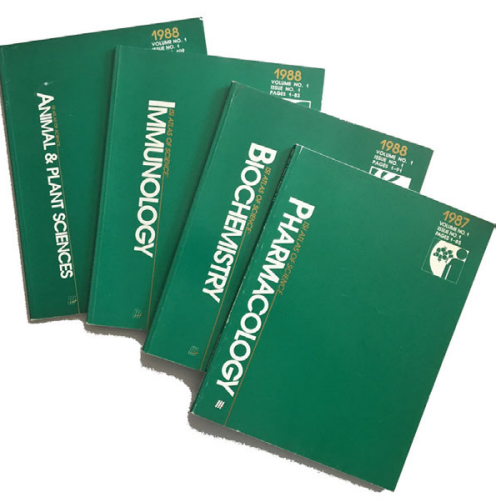

FIGURE 2 | ISI Atlas of Science (scanned covers and diagrams reproduced with permission of Clarivate Analytics). 
the limit with new developments, the various editors and advisors Gene hired could not agree on the direction to take. Eventually, a biweekly tabloid size publication on newsprint was released in October 1986 (Garfield, 1986).

As I mentioned, when Gene lost control of ISI, he managed to negotiate ownership of The Scientist and he kept it going as a personal venture for many years. As ever, Gene was very attuned to the practical uses of new technology and The Scientist became the first print publication, as far as we know, to be made available in full text on the internet, published weekly on a Gopher site and subsequently on the web. I became involved with Gene again in 1997, when I became the publisher of The Scientist. Gene was intimately involved with the publication-he read every article before it was published. He wrote editorials in the same vein as his Current Comments column, and he constantly pushed for the editorial staff to use citation data to identify "hot" scientists and areas of research. I will not go into further detail about the twists and turns of The Scientist story, thought there is plenty to tell. In 2002, Gene became partners with Vitek Tracz, and the magazine hired some top-class editorial talent. Now, 31 years after its foundation, The Scientist continues as a monthly print magazine and a daily web-based news service.

\section{HISTCITE}

Gene's final entrepreneurial venture, of which he was justifiably very proud, was the development of HistCite, a software program that allowed the user to create chronological maps and citation analyses of small datasets from Web of Science data.

As with many of Gene's projects, this one had a long gestation. In 1964, Gene wrote a report, along with ISI colleagues, which starts with the provocative question: "Can a computer write the history of science?" (Garfield et al., 1964). In fact, Gene had been thinking about this possibility from the very start, when he was developing his ideas for a citation index for the sciences.

The 1964 report tested the provocative opening question by creating citation maps from the recently developed SCI relating to the discovery of the structure of DNA, and comparing the algorithmic history of citation linkages with a "real" history of the topic written by science writer Isaac Asimov (1963). Crick, Watson and Wilkins had received their Nobel Prize for this work in 1962, so it was very much a hot topic. Using an elaborate system of hand-drawn transparencies, Gene and his colleagues overlaid the citation history of this discovery on Asimov's narrative. Happily, the analysis (and I quote) "demonstrated a high degree of coincidence between an historian's account of events and the citational relationship between these events (Figure 3)."

In the figure, one can see how painstaking the process of creating "historiographs" was in 1964, when there were no computer graphics tools, and data analysis was conducted entirely on a mainframe computer running in batch mode. So, Gene put this idea on the backburner for 35 years, by which time everyone had small fast computers capable of on demand data analysis and graphics. Working with his Russian colleague, Alexander Pudovkin and programmer, Vladimir Istomin, they created the software known as "HistCite." Gene started a small company, which I managed, and we released the program commercially in 2006 (Garfield, 2007).

Gene published many studies of individuals and research fields using HistCite (Garfield, 1973-1993), and it was used

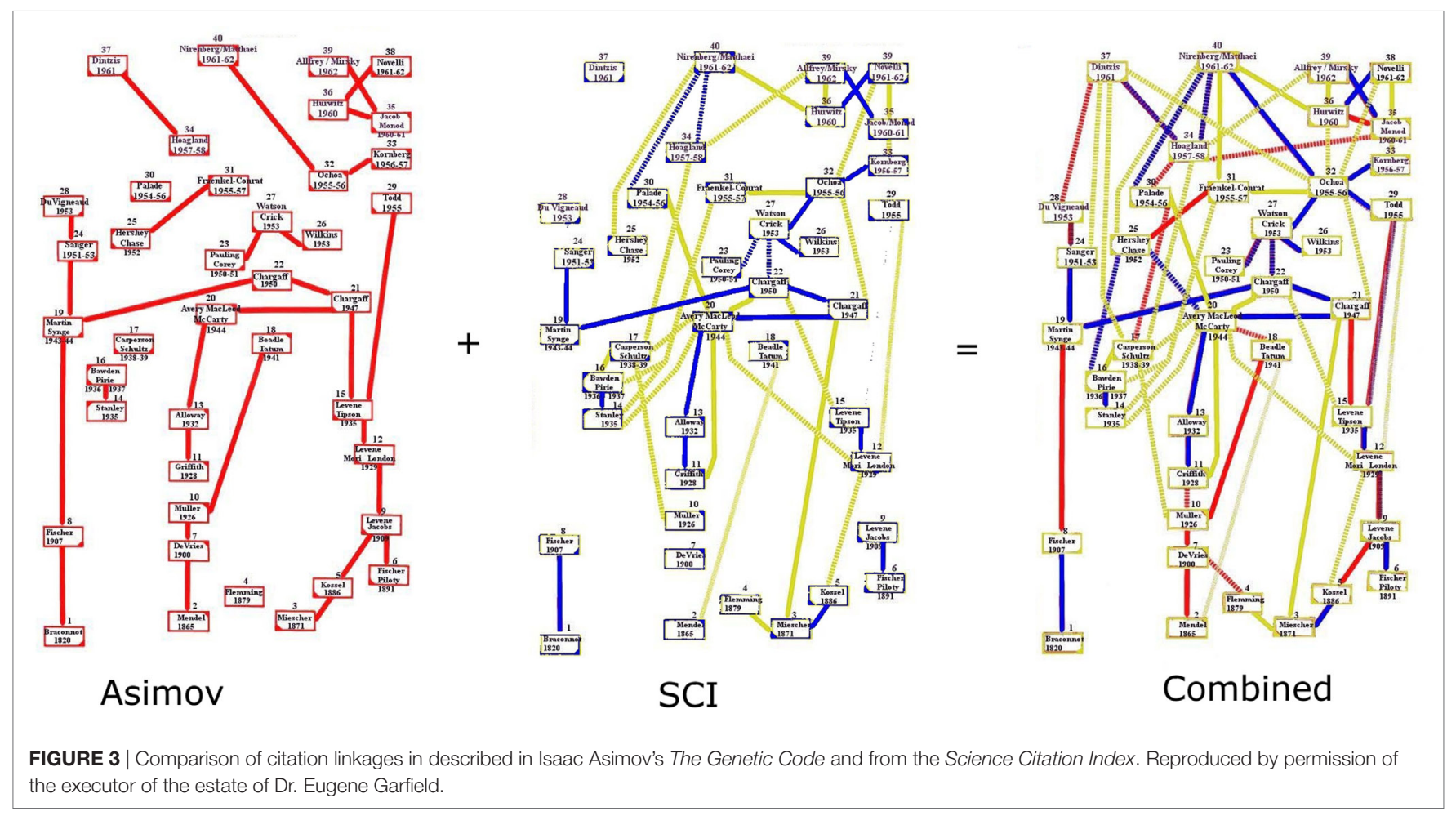


by several other bibliometricians. However, it did not sell widely and was eventually taken over by Thomson Reuters and rolled up with the Web of Science, where it is still available.

It was a great privilege to know Eugene Garfield, to see him in action, to argue with him, to learn from him, and to be his friend and colleague for over 30 years. He was a uniquely curious,

\section{REFERENCES}

Asimov, I. (1963). The Genetic Code. New York: New American Library.

Garfield, E. (2002-2012). Index of HistCite Analyses. Available at: http://garfield. library.upenn.edu/histcomp/

Garfield, E. (1973-1993). Essays of an Information Scientist, Vol. 15. Philadelphia: ISI Press. Available at: http://www.garfield.library.upenn. edu/essays.html

Garfield, E. (1977). Introducing Citation Classics: the Human Side of Scientific Reports. Current Contents, 1-2. Available at: http://www.garfield.library.upenn. edu/essays/v3p001y1977-78.pdf

Garfield, E. (1981). ISI Atlas of Science: Biochemistry and Molecular Biology, 1978/80. Philadelphia: Institute for Scientific Information.

Garfield, E. (1984). ISI Atlas of Science: Biotechnology and Molecular Genetics 1981/82. Philadelphia: Institute for Scientific Information.

Garfield, E. (1986). Introducing The Scientist: At Last, a Newspaper for the Science Professional. Current Contents, 3-6. Available at: http://garfield.library.upenn. edu/essays/v9p222y1986.pdf

Garfield, E. (1987). Launching the ISI Atlas of Science: For the New Year, a New Generation of Reviews. Current Contents, 1-8. Available at: http://garfield. library.upenn.edu/essays/v10p001y1987.pdf inventive, energetic, and creative individual who left a lasting mark on everything he touched.

\section{AUTHOR CONTRIBUTIONS}

The author confirms being the sole contributor of this work and approved it for publication.

Garfield, E. (2007). "From the science of science to scientometrics: visualizing the history of science with HistCite software," in Proceedings of ISSI 11th International Conference of the International Society for Scientometrics and Informetrics, Vol. 1 (Madrid, Spain: CSIC), 21-26. Available at: http://garfield. library.upenn.edu/papers/issiprocv1p21y2007.pdf

Garfield, E. (2009). Historical and Biographical Interview on the Web of Stories. Available at: https://www.webofstories.com/play/eugene.garfield/1

Garfield, E., Sher, I. H., and Torpie, R. J. (1964). The Use of Citation Data in Writing the History of Science. Philadelphia: Institute for Scientific Information. Available at: http://www.garfield.library.upenn.edu/papers/useofcitdatawritinghistofsci.pdf

Conflict of Interest Statement: The author declares that the research was conducted in the absence of any commercial or financial relationships that could be construed as a potential conflict of interest.

Copyright (C) 2018 Grimwade. This is an open-access article distributed under the terms of the Creative Commons Attribution License (CC BY). The use, distribution or reproduction in other forums is permitted, provided the original author(s) and the copyright owner are credited and that the original publication in this journal is cited, in accordance with accepted academic practice. No use, distribution or reproduction is permitted which does not comply with these terms. 